\title{
Notch Signaling Modulates the Activation of Microglial Cells
}

\author{
LUC GRANDBARBE, ALESSANDRO MICHELUCCI, TONY HEURTAUX, KARIN HEMMER, \\ ELEONORA MORGA, AND PAUL HEUSCHLING* \\ Department of Life Sciences, University of Luxembourg, Luxembourg
}

\section{KEY WORDS}

Jagged1; pro-inflammatory cytokines; Hes1; STAT3; nitric oxide

\begin{abstract}
The Notch signaling pathway plays a crucial role in specifying cellular fate in metazoan development by regulating communication between adjacent cells. Correlative studies suggested an involvement of Notch in hematopoietic cell development. Here, we report that the Notch pathway is expressed and active in microglial cells. During inflammatory activation, the transcription of the Notch down-stream effector Hes1 is downregulated. When Notch1 transcription in microglia is inhibited, an upregulation of the expression of pro-inflammatory cytokines is observed. Notch stimulation in activated microglia, using a soluble form of its ligand Jagged1, induces a decrease in pro-inflammatory cytokines secretion and nitric oxide production as well as an increase in phagocytic activity. Notch-stimulation is accompanied by an increase in the rate of STAT3 phosphorylation and nuclear translocation. Our results show that the Notch pathway plays an important role in the control of inflammatory reactions in the CNS. ๑2007 Wiley-Liss, Inc.
\end{abstract}

\section{INTRODUCTION}

Microglia, the CNS-resident cells of the myeloid cell lineage, is the primary competent actor for the innate as well as the adaptive immune response in the brain. During embryogenesis, these cells invade the CNS tissue and contribute to the removal of dead cells and debris occurring during the shaping of the developing brain. In the postnatal CNS, microglia acquires a highly differentiated phenotype, characterized by a ramified morphology. These cells are often referred to as quiescent or resting microglia, although they are active and contribute to the brain homeostasis and the neuronal survival (Kreutzberg, 1996; Nimmerjahn et al., 2005; Streit et al., 2005).

Resting microglia is able to rapidly react to a wide array of acute and chronic insults (Davalos et al., 2005; Nimmerjahn et al., 2005). This activation process results in a change in morphology, initiation of chemotaxis, and a profound modification of the transcription profile. Activated microglia is the source of numerous proinflammatory products, such as chemokines, cytokines, arachidonic acid derivates, reactive oxygen, and nitrogen intermediates. Since such a microenvironment is likely to be deleterious for the fragile neuronal network, proinflammatory microgliosis is suspected to be profoundly implicated, directly or indirectly, in the course of several neurodegenerative diseases like Alzheimer's disease (Akiyama et al., 2000; Gao et al., 2003; Sastre et al., 2006).

For the immune surveillance function, microglial cells, like macrophages, rely on the expression of pattern-recognition receptors like the TLRs, scavenger-receptors, Fc, and complement-receptors (Husemann et al., 2002; Lee and Lee, 2002; McGeer et al., 2005). Signaling through diffusible mediators, like cytokines, chemokines, or arachidonic acid derivates, will help to adapt the cellular response (Akiyama et al., 2000). Since microglial cells are tightly integrated into a dense tissue, numerous cellular contacts with neighboring cells are established (Davalos et al., 2005; Nimmerjahn et al., 2005). It thus seems likely that cell-contact mediated signaling will also play an important role during the activation process of microglial cells.

The Notch family of receptors regroups proteins with a single transmembrane domain (Artavanis-Tsakonas et al., 1999; Hansson et al., 2004). Four different Notch receptor genes have been identified in mammals, Notch1, 2, 3, and 4 (Mumm and Kopan, 2000). Five different Notch ligands, also showing a single transmembrane domain, have been identified: Jagged1 and 2, Delta1, 3, and 4 (Hansson et al., 2004). Both receptors and ligands exhibit epidermal growth factor-like extracellular repeats and interact via their Delta/Serrate/Lag (DSL) domain located adjacent to the N-terminus of the protein. Upon effective ligand binding, Notch receptors undergo proteolytic cleavage releasing the intracellular Notch receptor region/translocation-associated Notch homologue-1, NICD (Notch IntraCellular Domain). NICD is then translocated towards the nucleus, where it associates with the transcription factor CBF1/Suppressor of Hairless/LAG-1/RBP-Jk (CSL) (for review, Baron, 2003). In the absence of NICD, CSL is normally associated

\footnotetext{
Grant sponsors: National Research Fund; Ministry of Culture, Higher Education and Research; University of Luxembourg.

*Correspondence to: Paul Heuschling, Department of Life Sciences, University of Luxembourg, 162a, avenue de la Faiencerie, Luxembourg L-1511.

E-mail: paul.heuschling@uni.lu

Received 28 December 2006; Revised 22 June 2007; Accepted 27 June 2007

DOI 10.1002/glia.20553

Published online 17 August 2007 in Wiley InterScience (www.interscience. wiley.com).
} 
with corepressors, actively inhibiting transcription. NICD will displace the corepressors, recruit coactivators, and initiate CSL-dependent transcription. The most important known target genes are members of the Hes (basic helix-loop-helix Homolog Enhancers of Split) family of transcription factors, including Hes 1 and Hes 5 (Ohishi et al., 2003). Although some CSL-independent Notch signaling can occur, its mechanism is not well characterized (Zlobin et al., 2000).

Signaling through the Notch receptors is involved in the development of several cell types and the modulation of these signals can markedly affect differentiation, proliferation, and apoptotic events (Kimble and Simpson, 1997; Weinmaster, 1997). Activation of the pathway has been shown to be an important fate decision signal in different developmental contexts and has been associated with the proliferation of several somatic stem cell lines, such as the neural and hematopoietic stem cells (Shen et al., 2004; Varnum-Finney et al., 2000). A number of studies have implicated Notch signaling in lymphoid cell line commitment, thymic $\mathrm{T}$ cell development, and myeloid cell differentiation (Izon et al., 2002; Radtke et al., 1999; Washburn et al., 1997; Wolfer et al., 2001). The role of Notch signaling is not confined to the developmental process but seems to play an important role in the mature tissues. A modulatory role during macrophage activation has been recently documented (Monsalve et al., 2006). The stabilization of the neuronal networks in the mature CNS appears to depend on Notch signaling (Sestan et al., 1999). Demyelinating lesions induce an upregulation of the expression of Notch ligands (John et al., 2002).

Here, we provide evidence for a new role of Notch signaling in the mature CNS. We show that microglia express Notch receptors, and that this pathway is functional. In addition, pro-inflammatory activations silence Hes1 transcription in microglial cells. By decreasing expression of Notch receptors, we succeed in enhancing some pro-inflammatory parameters. On the other hand, an activation of the signaling pathway by soluble ligands reduces the inflammatory response of activated microglia and stimulates phagocytosis. Our results show that Notch activation modulates STAT3 phosphorylation and nuclear translocation in activated microglia. Thus, Notch signaling appears to be an instrument for the control of inflammatory reactions in the CNS.

\section{MATERIAL AND METHODS Cell Culture}

For primary microglia, primary mixed glial cell cultures were prepared from the brains of newborn Wistar rat pups as previously described (Morga et al., 2000). Briefly, after carefully removing meninges and large blood vessels, the brains were pooled and then minced in cold phosphate-buffered salt solution. The dissociation was completed by $10 \mathrm{~min}$ incubation in $1 \mathrm{mM}$ EDTA and passage through a nylon mesh (pore size, $100 \mu \mathrm{m}$ ). The cells were allowed to attach and grow at $37^{\circ} \mathrm{C}$ in DMEM supplemented with $20 \%$ fetal calf serum, penicillin (100 $\mathrm{U} / \mathrm{mL})$, and streptomycin $(100 \mu \mathrm{g} / \mathrm{mL})$ in a water-saturated atmosphere containing $5 \% \mathrm{CO}_{2}$. After 4 days, the cells were moved to $10 \%$ fetal calf serum-containing DMEM, which was replaced twice a week. After 10-14 days, when the cultures reached confluence, microglia was detached by two $8 \mathrm{~h}$ shakings on a rotary shaker. Microglial cells were then moved to $10 \%$ FCS-containing DMEM. Primary microglia was activated with LPS at $0.001 \mu \mathrm{g} / \mathrm{mL}$, since higher concentrations affect its cell survival. For experiments requiring larger amounts of material, the MMGT12 microglial cell line was used (Figs. 2, 4, 5B,C, 6, 7). This cell line presents a behavior comparable to that of primary microglia (Balboa et al., 2001; Briers et al., 1994; Hemmer et al., 2001).

The murine microglial cell line MMGT12, a generous gift from Dr. Vanmechelen, Innogenetics, Gent (Belgium), was cultured in DMEM/Ham's F12 (1/1), supplemented with 2\% FCS (Invitrogen, Scotland), 1\% ITS (Insulin-Transferrin-Selenium, Invitrogen), and $15 \%$ filtered conditioned medium of WEHI cells (WEHI 3, WEHI 3B, and WEHI 3D, ATCC, Rockville, MD). No antibiotics were used. The cells were grown at $37^{\circ} \mathrm{C}$ in a water-saturated incubator at $5 \% \quad \mathrm{CO}_{2}$ and passaged twice a week.

For experiments, MMGT12 microglial cells were seeded into multiwell plates at a density of $10^{4}$ cells $/ \mathrm{mL}$ in DMEM/F12, 10\% FCS, and 1\% ITS (experimental medium). After 2 days of culture, cells were activated by adding different stimuli to the culture medium as indicated in the text: lipopolysaccharide (LPS; $0.01 \mu \mathrm{g} / \mathrm{mL}$ ), interferon- $\gamma(\mathrm{IFN}-\gamma ; 100 \mathrm{U} / \mathrm{mL})$, and tumor necrosis factor- $\alpha$ (TNF- $\alpha ; 10 \mathrm{ng} / \mathrm{mL})$.

Two types of soluble Jagged1 have been used. For the experiments described in Figs. 5B,C and 7, we have used conditioned medium enriched with a soluble form of human Jagged1, produced from NIH-3T3 cells stably transfected with the human Jagged1 extracellular domain (hJaggedEC-3T3 cells, a generous gift from Prof. Artavanis-Tsakonas, Collège de France, Paris, France and Harvard Medical School, Boston, USA) (Sestan et al., 1999). hJaggedEC-3T3 cells and untransfected 3T3 cells (used as control) were treated as described (Grandbarbe et al., 2003). For the other experiments, $1 \mu \mathrm{g} / \mathrm{mL}$ of recombinant rat Jagged1 (R\&D Systems, UK) was used as a tool for Notch activation. This concentration was established by concentration-response experiments. The results obtained, with the concentration of $1 \mu \mathrm{g} / \mathrm{mL}$ of recombinant rat Jagged1, were the same as those obtained with the soluble form of human Jagged1.

\section{Treatment with Antisense Oligonucleotides and Notch1 siRNA}

The antisense oligonucleotides were designed against the EGF repeat region of the Notch1 gene. Nonsense oligonucleotides were used as a control and contained the same ratio of base pairs found in the antisense oligonucleotides but in a random order. The sequence for the 
antisense oligonucleotide was 5'-GAA GTC ATT AAC ACG CTG CAC AC, and for the nonsense oligonucleotide 5 '-TAC ATC AGC AGA CTA CAC GAG TC. The oligonucleotides were purified by HPLC (Eurogentec, Belgium). Microglial cells were treated with the oligonucleotides at a final concentration of $5 \mu \mathrm{M}$ during $48 \mathrm{~h}$.

Transfections with Notch1 siRNA (to a final concentration of $100 \mathrm{nM}$ ) were carried out in the six-well plates on primary microglia using Lipofectamine 2000 (Invitrogen) for $48 \mathrm{~h}$. Notch1-specific siRNA duplex was $5^{\prime}$ UUG AUG UCG AUC UCG CAG G and 5'-CCU GCG AGA UCG ACA UCA A, and siRNA negative control duplex were ordered from Eurogentec.

\section{RT-PCR Analysis}

Total RNA was purified from cultured cells using the SV Total RNA Isolation System (Promega, CA). RNA analysis was performed with RNA electrophoresis Experion system (Biorad, CA) to check the quality of RNA and to confirm the absence of genomic contamination. RNA was reverse transcribed using the ImProm-II Reverse Transcription System (Promega) with $0.5 \mu \mathrm{g} /$ reaction oligo $(\mathrm{dT})$ as primer and $1 \mu \mathrm{g}$ of total RNA. The RNA and oligo-dT were denaturated by preheating to $70^{\circ} \mathrm{C}$ for $5 \mathrm{~min}$ followed by an immediate chill in ice water for at least $5 \mathrm{~min}$. The reverse transcription reaction was performed in a total volume of $40 \mu \mathrm{L}$ containing ImProm-II $5 \times$ Reaction Buffer, $25 \mathrm{mM} \mathrm{MgCl}_{2}$, and 0.5 $\mathrm{mM}$ each of dATP, dTTP, dCTP, and dGTP for $1 \mathrm{~h}$ at $42^{\circ} \mathrm{C}$. For amplification, specific oligonucleotide primer pairs were incubated with $1 \mu \mathrm{L}$ cDNA and $0.8 \mathrm{U}$ Taq DNA Polymerase in a $25 \mu \mathrm{L}$ PCR Master Mix (Promega). Typical cycle conditions were $30 \mathrm{~s}$ at $94^{\circ} \mathrm{C}, 30 \mathrm{~s}$ at $55^{\circ} \mathrm{C}$, and $1 \mathrm{~min}$ at $72^{\circ} \mathrm{C}$. Twenty microliter of the resulting mix were then separated on a $2 \%$ agarose gel and visualized by ethidium bromide staining on a transilluminator. The primers for RT-PCR analysis were as follows: mouse Notch1 5'primer, TGC CAA ATG CCT GCC AGA AT and 3'primer, CAT GGA TCT TGT CCA TGC AG; mouse Notch2 5'primer, GAG GCG ACT CTT CTG CTG TTG AAG A and 3'primer ATA GAG TCA CTG AGC TCT CGG ACA G; mouse Jagged1 5'primer, TTA CTG TGG GAC TCA TCA GC and 3'primer TCA CAG TTC TGA CCC ATC CA; mouse Hes1 5'primer, CAG CCA GTG TCA ACA CGA CAC and 3'primer CTC GTT CAT GCA CTC GCT GA; mouse TNF- $\alpha$ 5'primer, CTC CCT CCA GAA AAG ACA CC and 3'primer TTT GGG GAC CGA TCA CCC CG; mouse IL-1 $\beta$ ' CCC AAA AGA TGA AGG GC and 3'primer ATG AGT CAC AGA GGA TGG GC; mouse IL-6 5'primer, TGC CTT CTT GGG ACT GAT GC and 3'primer GCC TCC GAC TTG TGA AGT GG; mouse $\beta$-actin 5 'primer, CGT GGG CCG CCC TAG GCA CCA and 3'primer TTG GCC TTA GGG TTC AGG GGG G; rat Hes1 5'primer, CAG CCA GTG TCA ACA CGA CAC and 3'primer CTC GTT CAT GCA CTC GCT GA; rat TNF- $\alpha$ 5'primer AGA ACT CCA GGC GGT GTC TGT and 3'primer CCT TGT CCC TTG AAG AGA ACC; rat NOSII 5'primer CTG CAT
GGA ACA GTA TAA GGC AAA $\mathrm{C}$ and 3'primer GAG ACA GTT TCT GGT CGA TGT CAT GA; rat IL-1 $\beta$ 5'primer TGA CTC GTG GGA TGA TGA CG and 3'primer ACC AGT TGG GGA ACT GTG CA; rat IL-6 5 'primer CAT TCT GTC TCG AGC CCA CC and 3 'primer GCC TCC GAC TTG TGA AGT GG and rat $\beta$ actin 5'primer, TCA CCG AGG CCC CTC TGA ACC CTA and 3'primer GGC AGT AAT CTC CTT CTG CAT CCT. "in silico" PCR AmplifiX 1.37 software was used to test our primers.

\section{Real-Time RT-PCR}

mRNA gene expression levels were determined after reverse transcription by real-time PCR by using a iQ5 Bio-Rad iCycler System (Bio-Rad, CA, USA). For the genes listed below, the relative expression was determined by using the SYBR Green PCR kit (Bio-Rad). Primer sequences designed using Beacon Designer software (Bio-Rad) were as follows: mouse Notch1 5'primer GCA GGC AAG ATG TTA ATG AGT G and 3'primer AGG GCA CAT AGG GCA GTT C; mouse Hes1 5'primer GCC AAT TTG CCT TTC TCA TCC and 3'primer GGT GAC ACT GCG TTA GGA C; mouse $\beta$-actin 5'primer AGG GAA ATC GTG CGT GAC ATC AAA GAG and 3'primer GGA GGA AGA GGA TGC GGC AGT GG; rat Notch1 5'primer CCG TGT GGC TTC CTT CTA C and 3'primer GGT TGG TGT CGC AGT TGG; rat Hes1 5'primer CCA ATT TGC TTT CCT CAT CCC and 3'primer GAA GGC GAC ACT GCG TTA G; rat TNF- $\alpha$ 5'primer GCT CTT CTG TCT ACT GAA CTT C and 3'primer GAT CTG AGT GTG AGG GTC TG; rat IL-1 $\beta$ 5'primer GTT GAA TCT ATA CCT GTC CTG TG and 3'primer TGG TCT TGA CTT CTA TCT TGT TG; rat IL-6 5'primer AAT CTG CTC TGG TCT TCT GG and 3'primer GTA TTG CTC TGA ATG ACT CTG G; rat $\beta$ actin 5'primer GCT GAG AGG GAA ATC GTG CGT GAC and 3'primer GGA GGA AGA GGA TGC GGC AGT GG.

cDNA was synthesized from total RNA by reverse transcriptase reaction by using ImProm-II Reverse Transcription System (Promega) with $0.5 \mu \mathrm{g} / \mathrm{reaction}$ oligo(dT) as primer. cDNA synthesized from $1 \mu \mathrm{g}$ of total RNA from MMGT12 microglial cells or from $200 \mathrm{ng}$ of total RNA from primary microglia, was used as template in each reaction. cDNA templates, measured with NanoDrop ND-1000 Spectrophotometer (NanoDrop, De, USA), were used at similar concentrations. For standardization of quantification, $\beta$-actin was amplified simultaneously. The change of reporter fluorescence from each reaction tube was monitored by iQ5 Real Time PCR Detection System. The threshold cycle of each gene was determined as PCR cycles at which an increase in reporter fluorescence above a baseline signal was observed. The difference in threshold cycles between the target gene and reference gene ( $\beta$-actin) gives the standardized expression level $(\mathrm{dCt})$. Subtraction of $\mathrm{dCt}$ of a defined control condition from $\mathrm{dCt}$ of different conditions gives the ddCt value that was used to calculate relative 
expression levels of different conditions with the formula $2^{-\mathrm{ddCt}}$. The expression levels of each gene were expressed as normalized fold expression.

Each sample was tested in triplicate PCR wells, and samples obtained from three independent experiments were used to calculate the mean \pm SEM.

\section{Immunostaining}

Microglial cells were fixed for $20 \mathrm{~min}$ in $4 \%$ paraformaldehyde in PBS ( $\mathrm{pH} 7.4$ ), washed in PBS and permeabilized 5 min with PBS/0.5\% Triton X-100 (Sigma, $\mathrm{MO})$. The cells were incubated overnight at $4^{\circ} \mathrm{C}$ in PBS containing $3 \% \mathrm{BSA}$ and the appropriate mixture of antibodies. The primary antibody used was mouse monoclonal anti-Notch1 (1/100, NEOMARKERS, CA). After washing in PBS, the cells were incubated for $1 \mathrm{~h}$ with Cy2-conjugated secondary antibodies (1/1,000, Jackson ImmunoResearch, PA). Control staining for nonspecific binding with an isotype-matched control antibody was realized. Preparations were counterstained with DAPI (1/1,000, Molecular Probes, OR), mounted in Fluoromount-G (Southern Biotechnology Associates, AL) and viewed for immunofluorescence using a Leica fluorescence microscope.

\section{Immunoblotting}

Cells were collected in phosphate buffered saline and lysed by repeated freeze/thaw cycles. Protein content of the lysates was determined with a microplate version of the Lowry assay, using bovine serum albumin standards. The lysates were separated by SDS-PAGE and blotted onto a supported nitrocellulose membrane. The blots were incubated overnight with the monoclonal goat anti-Notch1 antibody (C-20) (Santa Cruz Biotechnology, CA). For revelation by chemiluminescence, a peroxydase-conjugated AffiniPure Mouse Anti-Goat IgG (Jackson ImmunoResearch, PA) and SuperSignal West Femto Chemiluminescence Substrate (Pierce, IL) were used.

\section{Measurement of Phagocytosis}

Five hundred microliter of cell suspension (density of $4 \times 10^{4}$ cells $/ \mathrm{mL}$ ) were seeded into 48 -well microtiter plates. After $48 \mathrm{~h}$ at $37^{\circ} \mathrm{C}$, Jagged 1 was added at different concentrations and incubated during $24 \mathrm{~h}$. Yellowgreen FluoSpheres $(1 \mu \mathrm{m}$, Molecular Probes) were resuspended in $25 \mathrm{mM} \mathrm{NA}_{2} \mathrm{HPO}_{4}, \mathrm{pH} 6.0$ containing 3\% BSA and incubated at room temperature for $15 \mathrm{~min}$ with bath sonication. Fifty microliter of the sonicated suspension (containing $100 \times 10^{6}$ microspheres) were added to cultured microglia $\left(10^{5}\right.$ cells/well; $1 \mathrm{~mL}$ of culture medium/well). After $75 \mathrm{~min}$ at $37^{\circ} \mathrm{C}$, cells were washed three times with PBS and fluorescence was measured at $520 \mathrm{~nm}$ with a microplate reader (FLUOstar OPTIMA).
To differentiate between phagocytosed beads and beads that nonspecifically adhered to the cell surface, control cells were exposed to $0.3 \%$ azide for $10 \mathrm{~min}$ before the addition of microspheres. This treatment compromises microglial energetic processes and only a few beads are internalized as observed by fluorescent microscopy. The fluorescence of azide-treated MMGT12 microglial cells was used as the negative control. Background fluorescence of MMGT12 microglial cells cultured in the absence of fluorescent microspheres was less than $10 \%$ of the fluorescence values obtained using azide-treated MMGT12 microglial cells cultured in the presence of microspheres.

In the same experiments, we conducted luminescent cell viability assay to quantify the number of cells per well. The CellTiter-Glo luminescent cell viability assay (Promega) was used to determine the number of viable cells in culture.

\section{Nitric Oxide Release}

NO production was measured $48 \mathrm{~h}$ after LPS induction. The release of NO radicals was estimated by measuring the accumulation of nitrite in the culture supernatant by using the Griess reaction as previously described (Morga et al., 1998).

\section{Measurement of TNF- $\alpha$ and IL-6 Productions}

TNF- $\alpha$ and IL- 6 concentrations were measured using the DuoSet ELISA/Assay Development kit from R\&D Systems (MN, USA). TNF- $\alpha$ and IL-6 productions were measured in the culture supernatant $24 \mathrm{~h}$ after LPS exposure.

\section{STAT3 and NF-kB p65 Activation Assay}

Activation of $\mathrm{NF}-\kappa \mathrm{B}$ p65 was determined using the TransAM NF- $\mathrm{B}$ p65 transcription factor assay (Active Motif, CA) according to the manufacturer's recommendations. Nuclear extracts were prepared from microglial cells by hypotonic lysis. Nuclear lysates $(10 \mu \mathrm{g}$ of protein) were incubated in 96-well dishes containing immobilized oligonucleotides containing a NF- $\mathrm{KB}$ consensus DNA-binding site for $1 \mathrm{~h}$ at room temperature. Wells were then washed three times, and $100 \mu \mathrm{L}$ of NF- $\mathrm{NB}$ p65 monoclonal antibody (1/1,000) were added to each well for $1 \mathrm{~h}$ at room temperature. Wells were washed three times, and then $100 \mu \mathrm{L}$ of horseradish peroxidase-conjugated secondary antibody $(1 / 1,000)$ were added to each well for $1 \mathrm{~h}$ at room temperature. Wells were washed four times, and $100 \mu \mathrm{L}$ of developing solution were added to each well for $10 \mathrm{~min}$ at room temperature. Stop solution $(100 \mu \mathrm{L})$ was added to each well, and the absorbance at $450 \mathrm{~nm}$ was determined using an enzymelinked immunosorbent assay (ELISA) reader. Jurkat 
cells nuclear extracts were included as positive controls for $\mathrm{p} 65$.

Activation of STAT3 was determined using the TransAM STAT3 transcription factor assay (Active Motif) according to the manufacturer's recommendations. Nuclear extracts were prepared from microglial cells by hypotonic lysis. Nuclear lysates $(10 \mu \mathrm{g}$ of protein) were incubated in 96-well dishes containing immobilized oligonucleotides containing a STAT consensus DNA-binding site for $1 \mathrm{~h}$ at room temperature. Wells were then washed three times, and $100 \mu \mathrm{L}$ of STAT3 monoclonal antibody $(1 / 1,000)$ were added to each well for $1 \mathrm{~h}$ at room temperature. Wells were washed three times, and then $100 \mu \mathrm{L}$ of horseradish peroxidase-conjugated secondary antibody $(1 / 1,000)$ were added to each well for $1 \mathrm{~h}$ at room temperature. Wells were washed four times, and $100 \mu \mathrm{L}$ of developing solution were added to each well for $10 \mathrm{~min}$ at room temperature. Stop solution $(100 \mu \mathrm{L})$ was added to each well, and the absorbance at $450 \mathrm{~nm}$ was determined using an enzymelinked immunosorbent assay (ELISA) reader. Nuclear extracts from HepG2 cells (treated with IL-6, $100 \mathrm{ng} /$ $\mathrm{mL}$ ) were included as positive controls for STAT3.

\section{Statistical Analysis}

The data represent mean \pm SEM values from at least three independent experiments. For nitrite, TNF- $\alpha$, IL6, and STAT3 determinations, measurements were also done in triplicates. For comparison of means, obtained by ELISA, between two different treatments, statistical analysis was done by Student's $t$-test (two-sample assuming unequal variances). For comparison of multiple treatments, results were analyzed by an ANOVA followed by a Fisher's exact test.

\section{RESULTS \\ The Notch Pathway is Expressed in Resting and Activated Microglial Cells}

Notch1 receptor expression was detected on microglial cells in vitro. Primary microglial cells were stained with antibodies against the ligand binding region of the Notch1 receptor (Figs. 1A,B). All observed microglial cells were positive for Notch1-staining. Notch1 receptor is expressed in resting (Fig. 1A) and in LPS $(0.001 \mu \mathrm{g} /$ $\mathrm{mL}$ ) activated microglia (Fig. 1B). Activated microglia appeared to be more intensively stained (Fig. 1B).

In untreated MMGT12 microglial cells and in cells treated with LPS $(0.01 \mu \mathrm{g} / \mathrm{mL})$, IFN- $\gamma(100 \mathrm{U} / \mathrm{mL})$, or TNF- $\alpha$ (10 ng/mL) for 24 h, Notch1, Notch2, Jagged1, and Hes 1 transcripts are detected by RT-PCR. The expression levels were affected when cells were activated with LPS, IFN- $\gamma$, or TNF- $\alpha$ (Fig. 2A). After 24 h, Notch1 and Jagged1 expression increased in LPS activated cells (Fig. 2A). In contrast, Hes1 expression decreased under the same conditions (Fig. $2 \mathrm{~A}$ ). In IFN- $\gamma$ or TNF- $\alpha$ activation, the same tendencies were observed; in addition,
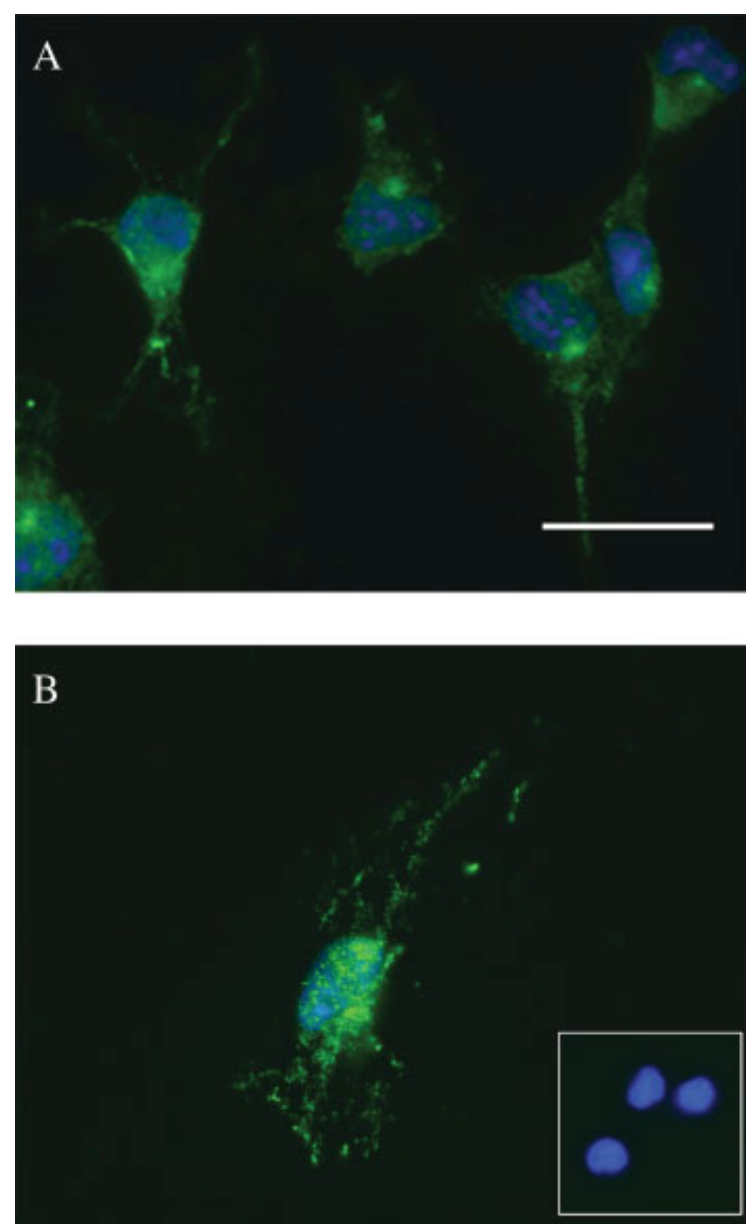

Fig. 1. Microglia cells express Notch1 receptor. Primary rat microglial cells were grown $24 \mathrm{~h}$ under control $(\mathbf{A})$ or LPS $(0.001 \mu \mathrm{g} / \mathrm{mL})(\mathbf{B})$ conditions. The cells were immunostained with antibodies against Notch1 (green). Nuclei were visualized by DAPI (blue). Scale bar: 20 $\mu \mathrm{m}$. Insert in (B) reduced image of cells showing control staining for nonspecific binding with an isotype control antibody. Nuclei were visualized by DAPI (blue).

Notch2 expression increased (Fig. 2A). The other genes of the Notch family like Notch3, Notch4, Jagged2, Delta1, and Hes5 were expressed in very low levels in microglial cells (data not shown). Figure $2 \mathrm{~B}$ shows that $6 \mathrm{~h}$ of LPS treatment on MMGT12 microglial cells also resulted in an increase in Notch 1 mRNA as determined with realtime RT-PCR. Showing a band at the expected molecular weight, Western blot analysis confirmed this upregulation of Notch1 expression in LPS activated MMGT12 microglial cells after $24 \mathrm{~h}$ (Fig. 2C). The time course of Hes 1 transcription during $24 \mathrm{~h}$ indicates that LPS treatment on MMGT12 microglial cells induced a continuous inhibition of Hes 1 mRNA as determined with real-time RT-PCR, while Hes 1 mRNA level oscillated in control MMGT12 over $24 \mathrm{~h}$ (Fig. 2D). Similar results were obtained with primary microglia (Figs. 2E,F).

These results show that the Notch pathway genes are active in the microglial cells that their expression is modified by activation and that Hes 1 transcription is repressed. 
A

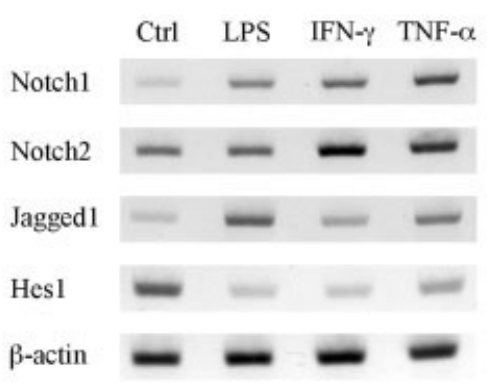

$\mathrm{C}$

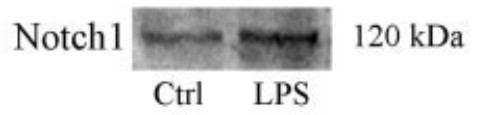

$\mathrm{E}$

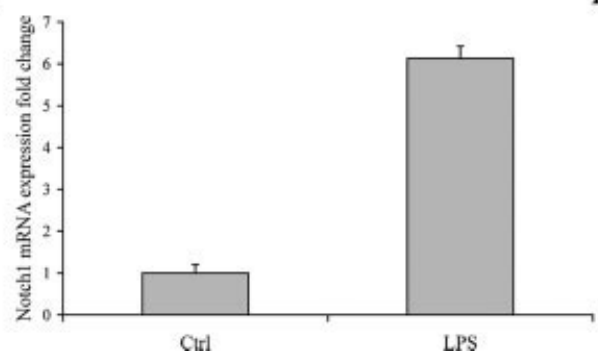

Cirl

Fig. 2. Transcription of Notch-pathway genes. (A) expression analysis of Notch1, Notch2, Jagged1, and Hes1 in MMGT12 microglial cells was studied using RT-PCR. RNA extraction was realized after $24 \mathrm{~h}$ of incubation. The cells were treated with either LPS $0.01 \mu \mathrm{g} / \mathrm{mL}$ or IFN- $\gamma$ $100 \mathrm{U} / \mathrm{mL}$ or TNF- $\alpha 10 \mathrm{ng} / \mathrm{mL}$. The number of PCR cycles was determined for each primer pair: 30 cycles for Notch 1 and Notch2, 32 cycles for Jagged 1, 36 cycles for Hes1, and 25 cycles for $\beta$-actin. (B) Induction of Notch1 mRNA in MMGT12 microglial cells treated with LPS $0.01 \mu \mathrm{g} /$ $\mathrm{mL}$ after $6 \mathrm{~h}$. Real-time quantitative RT-PCR results were normalized using $\beta$-actin as a calibrator gene and are shown as average expression fold change (with standard deviations) relative to Notch1 mRNA in control (Mean CT.ctrl.6h.Notch1 = 27.88; Mean CT.ctrl.6h. $\beta$-actin = 15.31). (C) Immunoblot analysis of Notch1 expression of MMGT12 microglial cells in the absence or presence of LPS $(0.01 \mu \mathrm{g} / \mathrm{mL})$. (D) Inhibition of Hes 1 mRNA in MMGT12 microglial cells in the absence or presence of

\section{The Notch Pathway is Functional in Microglia}

Invertebrate and vertebrate Notch activation can be mediated by soluble forms of ligands. As mentioned earlier, we used purified soluble rat Jagged1 as well as a secreted soluble human Jagged1 from transfected cells. The addition of Jagged1 on primary microglia resulted in morphological changes with outgrowth of processes (data not shown).

Moreover, to confirm the functional coupling of Notch in microglia, RT-PCR was realized to show if Notch ligands activate the expression of Notch effector Hes1. Treatments of primary microglial cells with Jagged1 showed an upregulation of the expression of Hes1 (Fig. 3). This upregulation of Hes1 was observed in con-
B

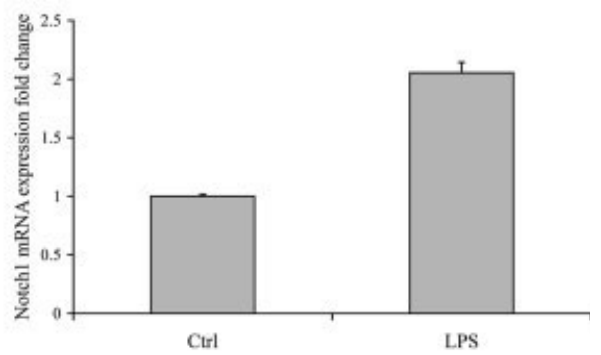

D

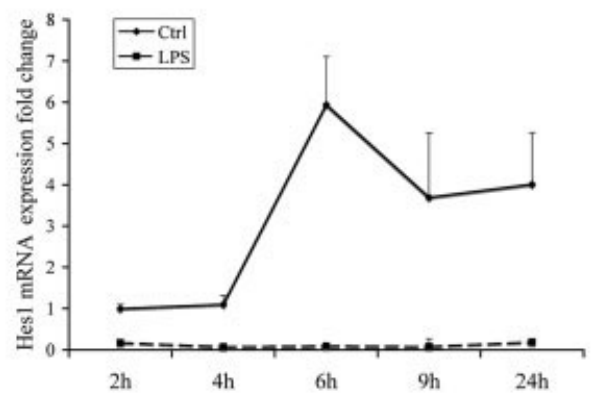

$\mathrm{F}$

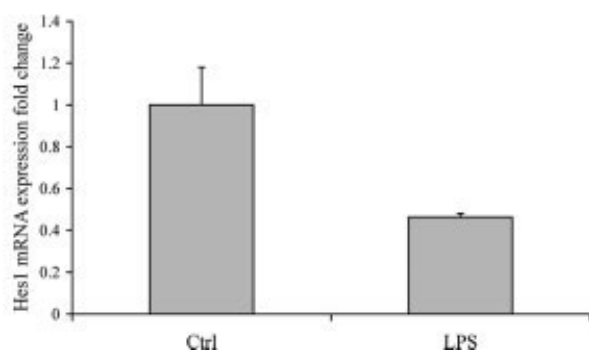

LPS $0.01 \mu \mathrm{g} / \mathrm{mL}$. Real-time quantitative RT-PCR results were normalized using $\beta$-actin as a calibrator gene and are shown as average expression fold change (with standard deviations) relative to Hes 1 mRNA in control conditions (Mean CT.ctrl.2h.Hes1 = 26.82; Mean CT.ctrl.2h. $\beta$ actin $=15.71)$. (E) Induction of Notch1 mRNA in primary microglia treated with LPS $0.001 \mu \mathrm{g} / \mathrm{mL}$ after $3 \mathrm{~h}$. Real-time quantitative RT-PCR results were normalized using $\beta$-actin as a calibrator gene and are shown as average expression fold change (with standard deviations) relative to Notch 1 mRNA in control (Mean CT.ctrl.2h.Notch $1=29.67$; Mean CT.ctrl.2h. -actin $=22.52)$ (Mean CT.ctrl.2h. Hes1 $=32.39 ;$ Mean CT.ctrl.2h.ß-actin = 22.54). (F) Inhibition of Hes 1 mRNA in primary microglial cells in the absence or presence of LPS $0.001 \mu \mathrm{g} / \mathrm{mL}$ after $3 \mathrm{~h}$. Real-time quantitative RT-PCR results were normalized using $\beta$-actin as a calibrator gene and are shown as average expression fold change (with standard deviations) relative to Hes 1 mRNA in control conditions.

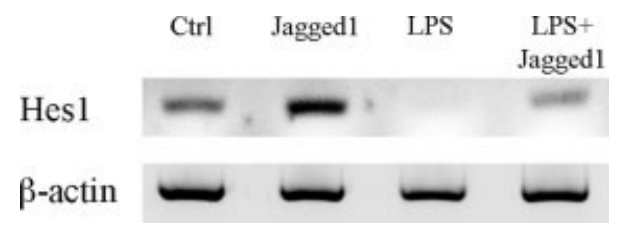

Fig. 3. RT-PCR expression analysis of Hes1 in primary microglial cells exposed to Jagged1. RNA extraction was realized after $6 \mathrm{~h}$. The primary microglial cells were treated with LPS $0.001 \mu \mathrm{g} / \mathrm{mL}$. The number of PCR cycles was determined for each primer pair: 36 cycles for Hes 1 and 25 cycles for $\beta$-actin.

trol condition as well as in the presence of LPS (Fig. 3). The same results were obtained with MMGT12 microglial cells (data not shown). 
A

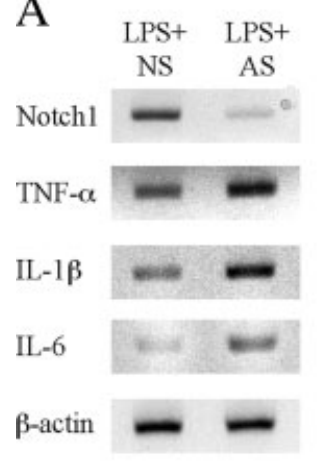

D

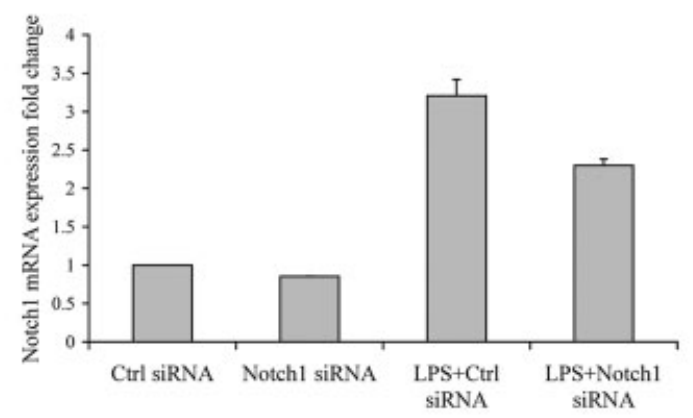

$\mathrm{F}$

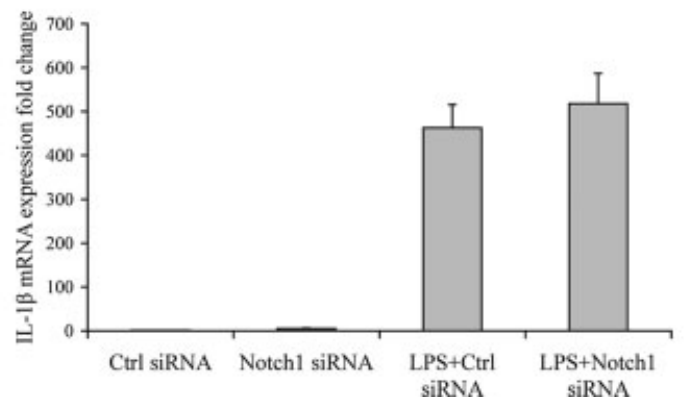

Fig. 4. Effects of Notch 1 down regulation on the transcription and release of pro-inflammatory cytokines. (A) RT-PCR analysis was used to assess the regulation of Notch $1, T N F-\alpha, I L-1 \beta$, and $I L-6$ expression in MMGT12 microglial cells in the presence of LPS $(0.01 \mu \mathrm{g} / \mathrm{mL})$ when exposed to nonsense (NS) or antisense (AS) oligonucleotides $(5 \mu \mathrm{M})$. RNA extraction was realized after $6 \mathrm{~h}$. The number of PCR cycles was determined for each primer pair: 30 cycles for Notch1, 25 cycles for $T N F$ - $\alpha, I L-1 \beta, I L-6$, and $\beta$-actin. (B) Notch1 antisense nucleotides increase activation-dependant TNF- $\alpha$ production. Antisense and nonsense oligonucleotides $(5 \mu \mathrm{M})$ were added to LPS-activated MMGT12 microglial cells and culture supernatants were collected after a $24 \mathrm{~h}$ incubation. TNF- $\alpha$ production data, obtained by ELISA are expressed as mean \pm SEM (bars) values obtained from three experiments, each conducted in independent cultures $(n=3)$. Results are expressed as pg/ $\mu \mathrm{g}$ of total proteins. Oligonucleotides alone induce no detectable level of TNF- $\alpha$ production. $* P<0.05$ when comparing LPS + NS with LPS + AS. (C) Notch1 antisense nucleotides increase activation-dependant IL-6 production. Antisense and nonsense oligonucleotides $(5 \mu \mathrm{M})$ were added to LPS-activated MMGT12 microglial cells and culture supernatants were collected after a 24 h-incubation. IL- 6 production data, obtained by ELISA are expressed as mean \pm SEM (bars) values obtained from three experiments, each conducted in independent cultures $(n=3)$. Results are expressed as pg/ $\mu \mathrm{g}$ of total proteins. $* * P<0.01$ when comparing LPS + NS with LPS+AS. (D) Notch1 siRNA decreased the levels of Notch 1 transcripts in primary microglia as confirmed by real-time
$\mathrm{C}$

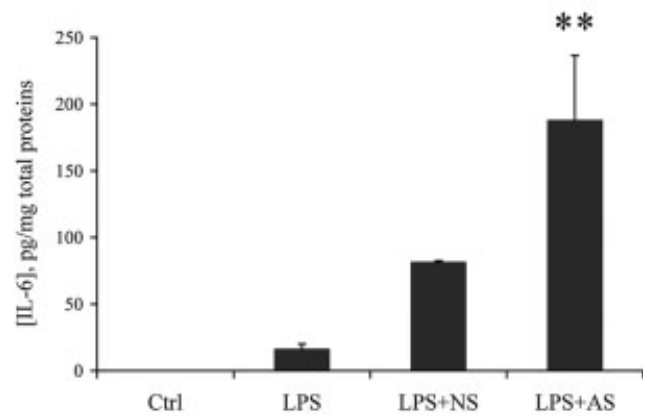

$\mathrm{E}$

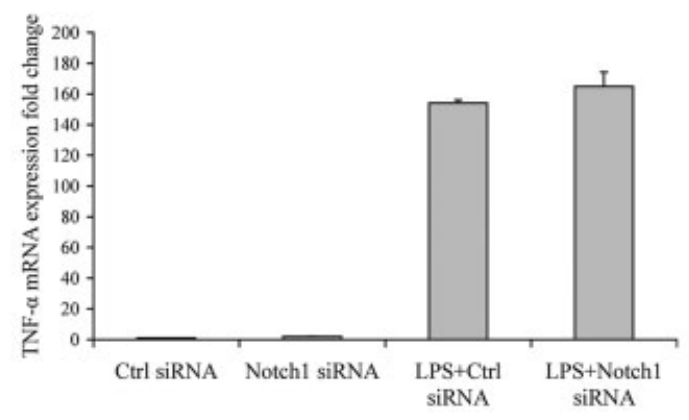

G

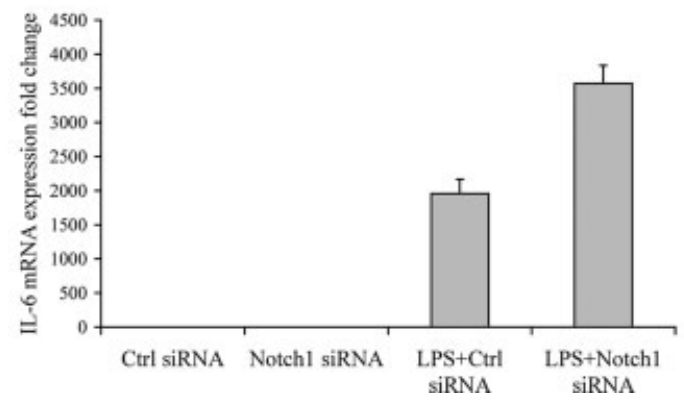

RT-PCR in the presence of LPS $(0.001 \mu \mathrm{g} / \mathrm{mL})$ after $6 \mathrm{~h}$. Real-time quantitative RT-PCR results were normalized using $\beta$-actin as a calibrator gene and are shown as average expression fold change (with standard deviations) relative to Notch 1 mRNA in control (Mean CT.ctrl.6h.Notch1 = 25.08; Mean CT.ctrl.6h.ß-actin $=17.97)$. (E) Notch1 siRNA slightly increased the levels of $T N F-\alpha$ transcripts in primary microglia as confirmed by real-time RT-PCR in the presence of LPS $(0.001 \mu \mathrm{g} / \mathrm{mL})$ after $6 \mathrm{~h}$. Real-time quantitative RT-PCR results were normalized using $\beta$-actin as a calibrator gene and are shown as average expression fold change (with standard deviations) relative to $T N F-\alpha$ mRNA in control (Mean CT.ctrl.6h. $T N F-\alpha=24.07$; Mean CT.ctrl.6h. $\beta$-actin = 17.97). (F) Notch1 siRNA slightly increased the levels of $I L-1 \beta$ transcripts in primary microglia, as confirmed by realtime RT-PCR in the presence of LPS $(0.001 \mu \mathrm{g} / \mathrm{mL})$ after $6 \mathrm{~h}$. Real-time quantitative RT-PCR results were normalized using $\beta$-actin as a calibrator gene and are shown as average expression fold change (with standard deviations) relative to $I L-1 \beta$ mRNA in control (Mean CT.ctrl.6h. $I L-1 \beta=22.64$; Mean CT.ctrl.6h. $\beta$-actin = 17.97). $(\mathbf{G})$ Notch1 siRNA increased significatly the levels of $I L-6$ transcripts in primary microglia as confirmed by real-time RT-PCR in the presence of LPS $(0.001 \mu \mathrm{g} / \mathrm{mL})$ after $6 \mathrm{~h}$. Real-time quantitative RT-PCR results were normalized using $\beta$-actin as a calibrator gene and are shown as average expression fold change (with standard deviations) relative to $I L-6$ mRNA in control (Mean CT.ctrl.6h. IL-6 $=29.04$; Mean CT.ctrl.6h. $\beta$ actin $=17.97$ ). 
These observations show that the Notch pathway is functional in microglia and that Jagged1 induces activation of this pathway under control and under inflammatory conditions.

\section{Effect of Notch1 Antisense and Notch1 siRNA Treatment on Microglial Activation}

The above described results suggest a possible physiological role of the Notch signaling during microglial activation. To assess if it has functional roles in microglia, antisense oligonucleotides were used to decrease the levels of Notch1 transcripts in MMGT12 microglial cells. The antisense oligonucleotide, designed against the EGF repeat coding region of the mouse Notch1 gene, has previously been shown to reduce Notch1 expression in neural cells in vitro (Austin et al., 1995). A series of oligonucleotide concentrations were tested and it was determined that the addition of $5 \mu \mathrm{M}$ antisense oligonucleotides provided optimal inhibition with no apparent toxicity (results not shown). All treatments were carried out by the addition of the oligonucleotide containing either antisense or nonsense sequences.

The treatment with antisense oligonucleotides effectively downregulated Notch1 expression in MMGT12 microglial cells activated with LPS $(0.01 \mu \mathrm{g} / \mathrm{mL})$, when compared with nonsense controls, confirming the specificity and efficacy of the oligonucleotide for Notch1 (Fig. 4A).

RT-PCR realized on RNA extracts after $6 \mathrm{~h}$ showed that addition of the antisense oligonucleotide to MMGT12 microglial cells treated with LPS $(0.01 \mu \mathrm{g} / \mathrm{mL})$ resulted in an increase in the production of $T N F-\alpha, I L$ $1 \beta$, and $I L-6$ transcripts, when compared with the nonsense control cultures (Fig. 4A). In addition, the secretion by MMGT12 cells of TNF- $\alpha$ and IL- 6 after $24 \mathrm{~h}$ was measured using an ELISA. The results showed that Notch 1 antisense oligonucleotide induced an increase in the production of TNF- $\alpha$ and IL- 6 in activated MMGT12 microglial cells (Figs. 4B,C).

Notch1 siRNA was used to decrease the levels of Notch1 transcripts in primary microglia. Downregulation of Notch1 by siRNA transfection showed less expression of Notch1 mRNA as confirmed by real-time RT-PCR (Fig. 4D). We have found that the downregulation of Notch1 expression in primary microglia, increased expression of IL- 6 mRNA induced by LPS treatment (Fig. 4G). The downregulation of Notch1 expression slightly increased the expression of $T N F-\alpha$ and $I L-1 \beta$ mRNA induced by LPS treatment in primary microglia (Figs. 4E,F).

Together these results suggest that Notch signaling modulates the transcription of several pro-inflammatory cytokines.

\section{Notch Activation Inhibits Production of Nitric Oxide and TNF- $\alpha$ in LPS-Activated Microglia}

To determine whether the observed overactivation of microglia is linked to the induced downregulation of
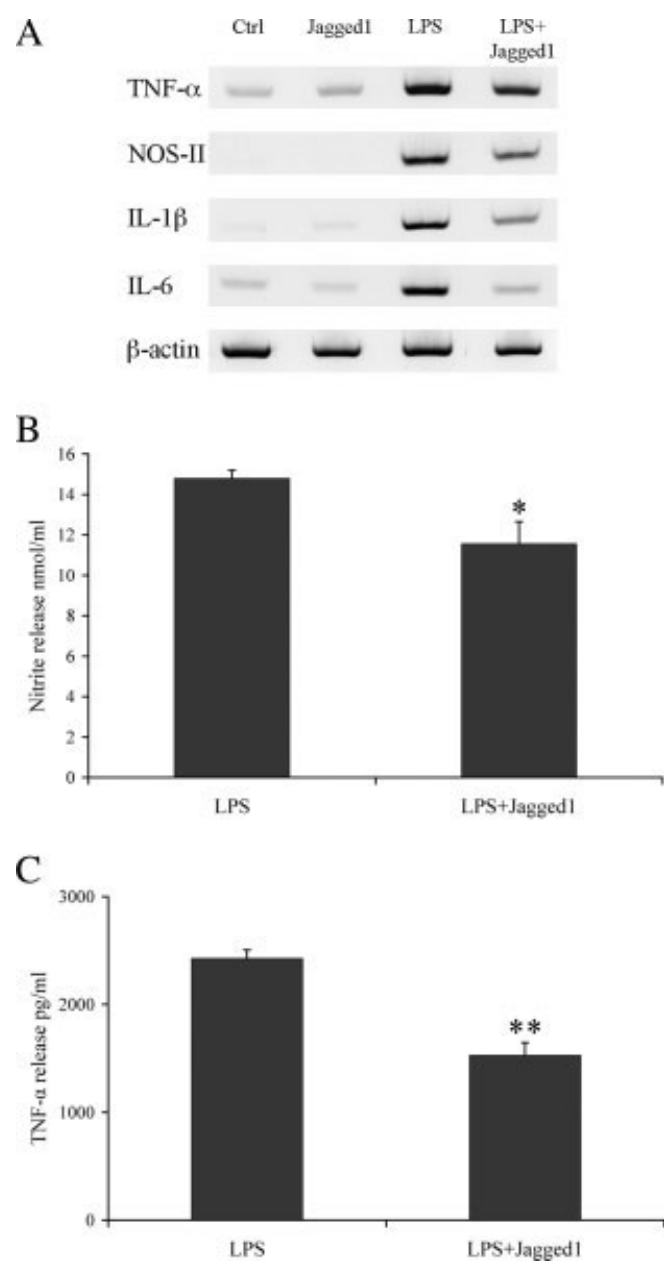

Fig. 5. Effects of Notch stimulation. (A) Ligand-induced Notch1 stimulation regulates the transcription levels of several genes. RT-PCR expression analysis was used to assess the regulation of $T N F-\alpha, N O S$ $I I, I L-1 \beta$, and $I L-6$ transcription in primary microglia in the presence of LPS $(0.001 \mu \mathrm{g} / \mathrm{mL})$ when exposed to Jagged1. RNA extraction was realized after $6 \mathrm{~h}$. The number of PCR cycles was determined for each primer pair: 28 cycles for $T N F-\alpha, 31$ cycles for $N O S-I I$ and $I L-6,26$ cycles for $I L-1 \beta$, and 25 cycles for $\beta$-actin. (B) Notch stimulation decreases the $\mathrm{NO}$ production by activated microglial cells. The $\mathrm{NO}_{2}{ }^{-}$ accumulation in the culture medium of MMGT12 microglial cells was measured in the presence of LPS $(0.01 \mu \mathrm{g} / \mathrm{mL})$. Culture supernatants were collected after a $48 \mathrm{~h}$-incubation. $\mathrm{NO}_{2}^{-}$accumulation data are analyzed by a modified Griess method and expressed as mean \pm SEM values obtained from three experiments, each conducted in independent cultures $(n=3)$. Results are expressed in $\mathrm{nmol} / \mathrm{mL}$. The data are corrected for the cell population values. ${ }^{*} P<0.05$. (C) Notch stimulation decreases the TNF- $\alpha$ secretion by activated microglial cells. Notch stimulation inhibits TNF- $\alpha$ production by MMGT12 microglial cells in the presence of LPS $(0.01 \mu \mathrm{g} / \mathrm{mL})$. Culture supernatants were collected after a $24 \mathrm{~h}$-incubation. TNF- $\alpha$ production was measured by ELISA and data are expressed as mean \pm SEM obtained from four experiments, each conducted in independent cultures $(n=4)$. Results are expressed in $\mathrm{pg} / \mathrm{mL}$. The data are corrected for the cell population values. $* * P<0.01$.

Notch1 expression, Notch stimulation with soluble ligand, Jagged1, was used before LPS activation. RTPCR realized on RNA extract after $6 \mathrm{~h}$ showed that addition of Jagged1 $(1 \mu \mathrm{g} / \mathrm{mL})$ to primary microglia treated with LPS $(0.001 \mu \mathrm{g} / \mathrm{mL})$ resulted in a decrease in the production of $T N F-\alpha, N O S-I I, I L-1 \beta$, and $I L-6$ transcripts, compared to cultures treated with LPS 


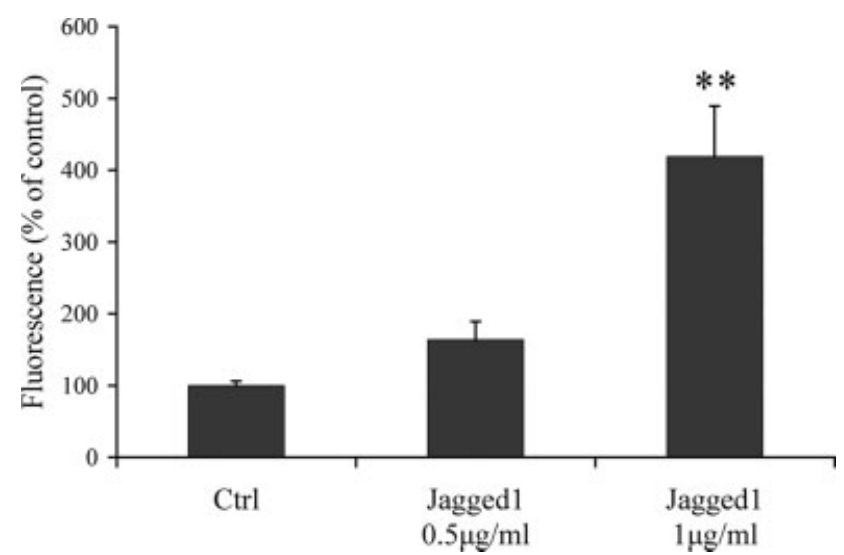

Fig. 6. Phagocytic activity of microglial cells exposed to Jagged1. Phagocytosis by MMGT12 microglial cells of fluorescent microspheres increases as a function of Jagged 1 concentration $(0.5 \mu \mathrm{g} / \mathrm{mL}$ and $1 \mu \mathrm{g} /$ $\mathrm{mL})$. After $48 \mathrm{~h}$ of cell incubation, Jagged 1 was added and cells further cultured during $24 \mathrm{~h}$. The microspheres were added to MMGT12 microglial cells for the last hour of the incubation time. Unbound microspheres were removed by washing and the fluorescence was determined. Data are corrected for the cell population values and are expressed as mean \pm SEM values obtained from three independent experiments $(n=3)$. Results are expressed relative to cultures without treatment. $* * P<0.01$.

alone (Fig. 5A). The same results were observed by RTPCR realized on MMGT12 microglial cells (data not shown).

In addition, in MMGT12 microglial cells, Jagged1 treatment induced a decrease of the NO released during the 48 h-incubation with LPS (Fig. 5B). Moreover, after $24 \mathrm{~h}$ of LPS exposure, a decrease in the production of TNF- $\alpha$ was observed in MMGT12 microglial cells when Jagged1 was provided (Fig. 5C). This suggests that Notch activation downregulates the pro-inflammatory cytokine-release as well as the NO production in activated microglial cells.

\section{Notch Activation Stimulates Phagocytosis}

Exposure of MMGT12 microglial cells to Jagged1 significatly increased the phagocytic activity, as assessed by fluorescent latex beads incorporation (Fig. 6). The concentration-dependent response showed significant differences at $1 \mu \mathrm{g} / \mathrm{mL}$ of Jagged1. These data established that the activation of Notch signaling favors phagocytosis in microglial cells.

\section{Notch Activation Induces STAT3 Phosphorylation}

Previous reports indicated that Notch signaling crosstalks with important pathways of inflammation like NF$\kappa \mathrm{B}$ pathway and JAK-STAT signaling. Thus, it should be possible that Notch signaling inhibits microglial activa-

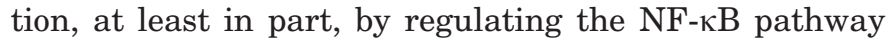
or JAK-STAT signaling.

As expected, LPS treatment increased the level of NF$\kappa \mathrm{B}$ p65 and phosphorylated STAT3 (phospho-STAT3) in the nucleus of MMGT12 microglial cells. For p65

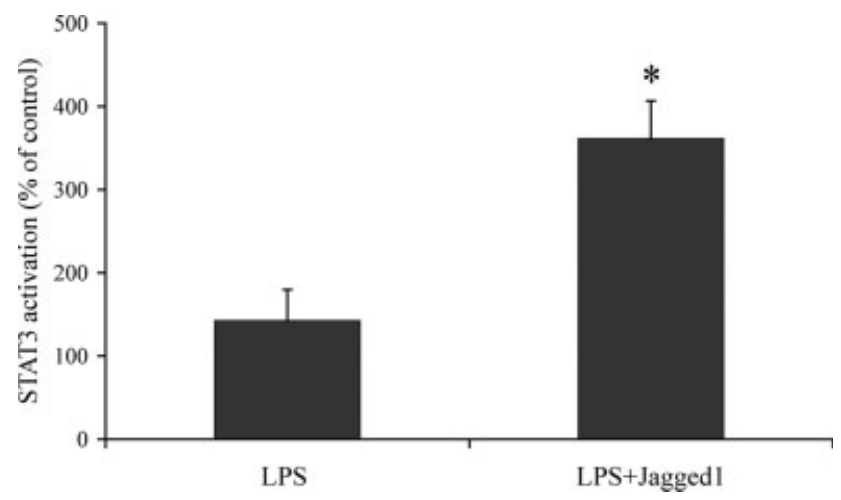

Fig. 7. Effect of Notch stimulation on STAT3 activation. Notch activation promotes STAT3 phosphorylation and nuclear translocation in MMGT12 microglial cells exposed to LPS $(0.01 \mu \mathrm{g} / \mathrm{mL})$. Nuclear fractions were collected after a 30 min-incubation. After binding to consensus DNA binding-regions, STAT3 concentrations are obtained by ELISA and are expressed as mean \pm SEM values obtained from three experiments, each conducted in independent cultures $(n=3)$. Results are expressed as a percentage of control $\left(100 \%=0.038\right.$ OD). ${ }^{*} P<0.05$.

and phospho-STAT3, the peak value in the nucleus is obtained after 30 min of LPS induction (data not shown).

Whereas p65 levels were not affected by the exposure to Jagged1 (data not shown), phospho-STAT3 translocation to the nucleus was significantly increased (Fig. 7).

\section{DISCUSSION}

Notch signaling is involved in multiple lineage decisions in the hematopoietic system. In the lymphoid lineage several developmental choices are regulated by Notch. The $\mathrm{T}$ versus B cell lineage choice (Izon et al., 2002; Koch et al., 2001), and the CD4 versus CD8 T cell decision (Hadland et al., 2001) are regulated by Notch signaling. In the myeloid lineage, Notch signaling has been implicated in the early transition from a granulocyte-monocyte progenitor to differentiated granulocyte, although there is controversy on the exact function of Notch in this cell lineage (Karanu et al., 2000; TanPertel et al., 2000; Walker et al., 1999).

Recently, a role for Notch signaling in fully differentiated immune cells has been clearly defined in macrophages (Monsalve et al., 2006). Resting macrophages express Notch receptors, as well as the Notch ligands. After treatment with LPS or IFN- $\gamma$, an increase in Notch1 and Jagged1 mRNA and protein levels is observed. Transfection-induced over-expression of truncated, active intracellular Notch1 (NICD) shows that Notch upregulation and subsequent signaling following macrophage activation modulate some pro-inflammatory gene expression patterns known to affect the function of mature macrophages (Monsalve et al., 2006).

In the present study, we provide first evidence that Notch signaling is functional in microglial cells. Here, we show that the receptors and ligands that constitute the Notch pathway are expressed in microglia. In our conditions, microglial cells produce significant levels of 
Notch1, Notch2, and Jagged1. In these cells, the expression of the downstream target of Notch cascade, Hes1 suggests that Notch signaling is functional. Our data show that Notch activation with soluble ligands induces upregulation of Hes1 transcripts.

During activation with different agents (LPS, IFN- $\gamma$, TNF- $\alpha$ ), microglial cells increase their expression of Notch1. However, in spite of the higher expression levels of the receptors, activated microglial cells present an almost silenced Hes1 transcription. These unexpected data seem to indicate that, during the activation of microglia, some pathways interact with the Notch signaling. Interestingly, stimuli that promote $\mathrm{I} \kappa \mathrm{B} \alpha$ degradation, p65 acetylation, and NF- $\mathrm{kB}$ activation, such as $\mathrm{TNF}-\alpha$, inhibit Notch-dependent transcriptional activity (Espinosa et al., 2003). Furthermore, Notch and NF-кB pathways might compete for nuclear corepressors (Aguilera et al., 2004; Espinosa et al., 2002). It is interesting to note that, in the absence of LPS, Hes1 mRNA levels oscillate in MMGT12 microglial cells during our time course study. These findings are consistent with observations concerning the cyclic expression of Hes1 in seruminduced cells (Hirata et al., 2002).

The functional role of Notch in microglia is demonstrated by an approach of modulation of Notch signaling. In a first step, we have decreased the expression of Notch1. Since TNF- $\alpha$, IL-1 $\beta$, and IL- 6 release by activated microglia are considered as markers of an active pro-inflammatory response, the present results provide evidence that decreased Notch signaling upregulates the initiation of inflammation in microglia. In a second step, the experiments of Notch activation with soluble ligand confirms the biological role of Notch signaling in microglial cells, decreasing the transcription levels of NOS-II, $T N F-\alpha, I L-1 \beta$, and $I L-6$ as well as the release of NO and TNF- $\alpha$. These results confirm and complete those recently reported by Monsalve et al. (2006) who show that Notch-stimulation in peritoneal macrophages reduces the NO production.

Microglia fails to efficiently remove amyloid deposits from the Alzheimer disease brain or its murine models. Indeed, serial three-dimensional reconstructions of $\beta$ amyloid plaques in an animal model of Alzheimer's disease revealed that $A \beta$ deposits were enveloped by microglial processes but were not internalized by microglia (Stalder et al., 2001). In our hands, beta-amyloid or LPS-activated microglial cells show a reduced phagocytic activity (results not shown), whereas Jagged1-exposure enhances microglial phagocytosis. It is not clear by which mechanism the phagocytic activity is regulated in these cells. An inhibition of the NF- $\mathrm{BB}$ pathway has been shown to increase phagocytosis in macrophages (Maiuri et al., 2004). An IL-10 induced increase in STAT3 phosphorylation also induces an increase in phagocytic activity (Petit-Bertron et al., 2003). As discussed below, our cells show a rise in STAT3 phosphorylation after Notch stimulation.

These experiments of inactivation or activation of Notch signaling suggest that this pathway help to maintain microglial cell in a quiescent state in normal conditions and inhibits over-activation during proinflammatory events. In CNS lesions, a re-expression of the Notch pathway is observed (Chen et al., 2005). In multiple sclerosis, Jagged1 is expressed at high levels by hypertrophic astrocytes (John et al., 2002). It should be possible that during inflammatory events, astrocytes express the Notch ligand Jagged1 to stimulate microglial Notch1 receptors in the lesions. In the same manner, under normal conditions, neurons could be an important source of ligands for activating Notch receptor in microglial cells. In mature cortical neurons, two Notch ligands, Delta1 and Jagged1, are expressed throughout the cerebral cortex and localized to neuronal bodies, neurites and synapses (Sestan et al., 1999). Thus, the re-expression of the Notch pathway, which is regarded as detrimental for neuronal and oligodendroglial differentiation (Sestan et al., 1999; Wang et al., 1998), could have beneficial effects on the regulation of inflammatory processes by microglia.

An important question is through which process the Notch pathway modulates the activation of microglia. It is conceivable that Hes1, a transcriptional repressor, directly regulates the transcription of cytokines like TNF- $\alpha$, IL-1 $\beta$, and IL-6. More likely, Notch signaling could crosstalk with important pathways of inflammation like NF- $\mathrm{KB}$ pathway, AP-1, or JAK-STAT signaling.

Our results show that the activation of Notch signaling has no effect on the NF- $\mathrm{kB}-\mathrm{p} 65$ activation. This is in agreement with findings reported by other teams (Chu et al., 2002; Monsalve et al., 2006). Nevertheless, several reports document an influence of the Notch pathway on NF-kB activation (Guan et al., 1996; Oakley et al., 2003; Wang et al., 2001). NICD could function, in a similar

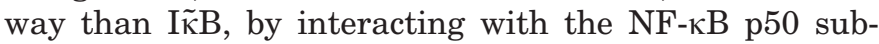
unit. Furthermore, the transcription of $\mathrm{I} \tilde{\mathrm{K}} \mathrm{B} \alpha$ is controlled by RBP-J and NICD (Oakley et al., 2003). Thus, we cannot entirely role out that interaction between the Notch pathway and NF-kB-p50 exists.

Notch-stimulation seems to inhibit the AP-1 dependant transcriptions (Chu et al., 2002; Monsalve et al., 2006). Although the role of AP-1 appears to be less prominent than that of $\mathrm{NF}-\mathrm{\kappa B}$, its inhibition could also have repercussions on the inflammatory behavior of microglial cells. Further experiments are needed to shed light on the possible interactions between the Notch and AP-1 pathways in microglia.

STAT3 is known as a potential negative regulator of inflammatory responses. STAT3 regulates innate immune responses at several levels, through downregulating NF- $\mathrm{kB}$ activation by TLRs, through inhibiting the growth response to cytokines such as granulocyte macrophage-CSF and macrophage-CSF, and through regulating an effector function of neutrophils, the NADPH oxidase activity (de Jonge et al., 2005; Takeda et al., 1999; Welte et al., 2003). Our data show an upregulation of STAT3 phosphorylation and nuclear translocation when Notch is activated with soluble ligand. A molecular support for these observations has been provided by recent findings showing that STAT3 is phosphorylated after Notch activation, as well as in the presence of the Notch 
effectors Hes1 and Hes5 (Kamakura et al., 2004). Hes proteins associate with JAK2 and STAT3, facilitating complex formation between these proteins, thus promoting STAT3 phosphorylation and nuclear translocation. Furthermore, suppression of endogenous Hes1 expression reduces the cytokine-dependant STAT3 phosphorylation (Kamakura et al., 2004). This mechanism could explain the increase in nuclear phospho-STAT3 we observe. This also sheds new light on our findings showing that activated microglia express lower levels of Hes1, thereby inducing lower phosphorylation of STAT3 and producing a more pro-inflammatory phenotype. Notch-stimulation increases Hes1 expression, favoring a higher phosphorylation of STAT3, which then correlates with inhibition of pro-inflammatory events.

In conclusion, we have shown here that microglial cells express the different components of the Notch signaling pathway and that, in these cells, the Notch pathway is functional. The results have shown that Notch activation reduces the pro-inflammatory activity of microglial cells. Our model predicts that Notch signaling is one possible process that maintains microglial cells in a resting state in the CNS. In normal conditions, neurons express Notch ligands, thus providing the signal capable of activating Notch in microglial cells. During inflammatory events in the CNS, one role of the Notch signaling should be to prevent an exagerated pro-inflammatory activation. Upregulation of Notch signaling is then possible because Jagged1 is expressed at high level in reactive astrocytes, whereas microglial cells expose more Notch receptors at their cell surface. The data presented here reveal a new role for the Notch pathway in the control of inflammation in the CNS.

\section{REFERENCES}

Aguilera C, Hoya-Arias R, Haegeman G, Espinosa L, Bigas A. 2004 Recruitment of IkappaBalpha to the hes1 promoter is associated with transcriptional repression. Proc Natl Acad Sci USA 101:16537-16542.

Akiyama H, Barger S, Barnum S, Bradt B, Bauer J, Cole GM, Cooper NR, Eikelenboom P, Emmerling M, Fiebich BL, et al. 2000. Inflammation and Alzheimer's disease. Neurobiol Aging 21:383-421.

Artavanis-Tsakonas S, Rand MD, Lake RJ. 1999. Notch signaling: Cell fate control and signal integration in development. Science 284:770776.

Austin CP, Feldman DE, Ida JA Jr, Cepko CL. 1995. Vertebrate retinal ganglion cells are selected from competent progenitors by the action of Notch. Development 121:3637-3650.

Balboa MA, Balsinde J, Dennis EA. 2001. Inflammatory activation of prostaglandin production by microglial cells antagonized by amyloid peptide. Biochem Biophys Res Commun 280:558-560.

Baron M. 2003. An overview of the Notch signalling pathway. Semin Cell Dev Biol 14:113-119.

Briers TW, Desmaretz C, Vanmechelen E. 1994. Generation and characterization of mouse microglial cell lines. J Neuroimmunol 52:153164.

Chen J, Leong SY, Schachner M. 2005. Differential expression of cell fate determinants in neurons and glial cells of adult mouse spinal cord after compression injury. Eur J Neurosci 22:1895-1906.

Chu J, Jeffries S, Norton JE, Capobianco AJ, Bresnick EH. 2002. Repression of activator protein-1-mediated transcriptional activation by the Notch-1 intracellular domain. J Biol Chem 277:7587-7597.

Davalos D, Grutzendler J, Yang G, Kim JV, Zuo Y, Jung S, Littman DR, Dustin ML, Gan WB. 2005. ATP mediates rapid microglial response to local brain injury in vivo. Nat Neurosci 8:752-758.

de Jonge WJ, van der Zanden EP, The FO, Bijlsma MF, van Westerloo DJ, Bennink RJ, Berthoud HR, Uematsu S, Akira S, van den Wijn- gaard RM, et al. 2005. Stimulation of the vagus nerve attenuates macrophage activation by activating the Jak2-STAT3 signaling pathway. Nat Immunol 6:844-851.

Espinosa L, Ingles-Esteve J, Robert-Moreno A, Bigas A. 2003. IkappaBalpha and p65 regulate the cytoplasmic shuttling of nuclear corepressors: Cross-talk between Notch and NFkappaB pathways. Mol Biol Cell 14:491-502.

Espinosa L, Santos S, Ingles-Esteve J, Munoz-Canoves P, Bigas A. 2002. p65-NFkappaB synergizes with Notch to activate transcription by triggering cytoplasmic translocation of the nuclear receptor corepressor N-CoR. J Cell Sci 115(Part 6):1295-1303.

Gao HM, Liu B, Zhang W, Hong JS. 2003. Novel anti-inflammatory therapy for Parkinson's disease. Trends Pharmacol Sci 24:395-401.

Grandbarbe L, Bouissac J, Rand M, Hrabe de Angelis M, ArtavanisTsakonas S, Mohier E. 2003. Delta-Notch signaling controls the generation of neurons/glia from neural stem cells in a stepwise process. Development 130:1391-1402.

Guan E, Wang J, Laborda J, Norcross M, Baeuerle PA, Hoffman T. 1996. T cell leukemia-associated human Notch/translocation-associated Notch homologue has I kappa B-like activity and physically interacts with nuclear factor-kappa B proteins in T cells. J Exp Med 183:2025-2032

Hadland BK, Manley NR, Su D, Longmore GD, Moore CL, Wolfe MS, Schroeter EH, Kopan R. 2001. Gamma-secretase inhibitors repress thymocyte development. Proc Natl Acad Sci USA 98:7487-7491.

Hansson EM, Lendahl U, Chapman G. 2004. Notch signaling in development and disease. Semin Cancer Biol 14:320-328.

Hemmer K, Fransen L, Vanderstichele H, Vanmechelen E, Heuschling P. 2001. An in vitro model for the study of microglia-induced neurodegeneration: Involvement of nitric oxide and tumor necrosis factoralpha. Neurochem Int 38:557-565.

Hirata H, Yoshiura S, Ohtsuka T, Bessho Y, Harada T, Yoshikawa K, Kageyama R. 2002. Oscillatory expression of the bHLH factor Hes1 regulated by a negative feedback loop. Science 298:840-843.

Husemann J, Loike JD, Anankov R, Febbraio M, Silverstein SC. 2002. Scavenger receptors in neurobiology and neuropathology: Their role on microglia and other cells of the nervous system. Glia 40:195205.

Izon DJ, Aster JC, He Y, Weng A, Karnell FG, Patriub V, Xu L, Bakkour S, Rodriguez C, Allman D, Pear WS. 2002. Deltex1 redirects lymphoid progenitors to the B cell lineage by antagonizing Notch1. Immunity 16:231-243.

John GR, Shankar SL, Shafit-Zagardo B, Massimi A, Lee SC, Raine CS, Brosnan CF. 2002. Multiple sclerosis: Re-expression of a developmental pathway that restricts oligodendrocyte maturation. Nat Med 8:1115-1121.

Kamakura S, Oishi K, Yoshimatsu T, Nakafuku M, Masuyama N, Gotoh Y. 2004. Hes binding to STAT3 mediates crosstalk between Notch and JAK-STAT signalling. Nat Cell Biol 6:547-554.

Karanu FN, Murdoch B, Gallacher L, Wu DM, Koremoto M, Sakano S, Bhatia M. 2000. The notch ligand jagged-1 represents a novel growth factor of human hematopoietic stem cells. J Exp Med 192:1365-1372.

Kimble J, Simpson P. 1997. The LIN-12/Notch signaling pathway and its regulation. Annu Rev Cell Dev Biol 13:333-361.

Koch U, Lacombe TA, Holland D, Bowman JL, Cohen BL, Egan SE, Guidos CJ. 2001. Subversion of the T/B lineage decision in the thymus by lunatic fringe-mediated inhibition of Notch-1. Immunity 15:225-236

Kreutzberg GW. 1996. Microglia: A sensor for pathological events in the CNS. Trends Neurosci 19:312-318.

Lee SJ, Lee S. 2002. Toll-like receptors and inflammation in the CNS. Curr Drug Targets Inflamm Allergy 1:181-191.

Maiuri MC, Tajana G, Iuvone T, De Stefano D, Mele G, Ribecco MT, Cinelli MP, Romano MF, Turco MC, Carnuccio R. 2004. Nuclear factor-kappaB regulates inflammatory cell apoptosis and phagocytosis in rat carrageenin-sponge implant model. Am J Pathol 165:115126.

McGeer EG, Klegeris A, McGeer PL. 2005. Inflammation, the complement system and the diseases of aging. Neurobiol Aging 26(Suppl 1): 94-97.

Monsalve E, Perez MA, Rubio A, Ruiz-Hidalgo MJ, Baladron V, GarciaRamirez JJ, Gomez JC, Laborda J, Diaz-Guerra MJ. 2006. Notch-1 up-regulation and signaling following macrophage activation modulates gene expression patterns known to affect antigen-presenting capacity and cytotoxic activity. J Immunol 176:5362-5373.

Morga E, Faber C, Heuschling P. 1998. Cultured astrocytes express regional heterogeneity of the immunoreactive phenotype under basal conditions and after gamma-IFN induction. J Neuroimmunol 87:179184.

Morga E, Faber C, Heuschling P. 2000. Stimulation of endothelin B receptor modulates the inflammatory activation of rat astrocytes. J Neurochem 74:603-612. 
Mumm JS, Kopan R. 2000. Notch signaling: From the outside in. Dev Biol 228:151-165.

Nimmerjahn A, Kirchhoff F, Helmchen F. 2005. Resting microglial cells are highly dynamic surveillants of brain parenchyma in vivo. Science 308:1314-1318.

Oakley F, Mann J, Ruddell RG, Pickford J, Weinmaster G, Mann DA. 2003. Basal expression of IkappaBalpha is controlled by the mammalian transcriptional repressor RBP-J (CBF1) and its activator Notch1. J Biol Chem 278:24359-24370.

Ohishi K, Katayama N, Shiku H, Varnum-Finney B, Bernstein ID. 2003. Notch signalling in hematopoiesis. Semin Cell Dev Biol 14:143150 .

Petit-Bertron AF, Fitting C, Cavaillon JM, Adib-Conquy M. 2003. Adherence influences monocyte responsiveness to interleukin-10. J Leukoc Biol 73:145-154.

Radtke F, Wilson A, Stark G, Bauer M, van Meerwijk J, MacDonald HR, Aguet M. 1999. Deficient T cell fate specification in mice with an induced inactivation of Notch1. Immunity 10:547-558.

Sastre M, Klockgether T, Heneka MT. 2006. Contribution of inflammatory processes to Alzheimer's disease: Molecular mechanisms. Int J Dev Neurosci 24:167-176.

Sestan N, Artavanis-Tsakonas S, Rakic P. 1999. Contact-dependent inhibition of cortical neurite growth mediated by notch signaling. Science 286:741-746.

Shen Q, Goderie SK, Jin L, Karanth N, Sun Y, Abramova N, Vincent P, Pumiglia K, Temple S. 2004. Endothelial cells stimulate self-renewal and expand neurogenesis of neural stem cells. Science 304:13381340.

Stalder M, Deller T, Staufenbiel M, Jucker M. 2001. 3D-Reconstruction of microglia and amyloid in APP23 transgenic mice: No evidence of intracellular amyloid. Neurobiol Aging 22:427-434.

Streit WJ, Conde JR, Fendrick SE, Flanary BE, Mariani CL. 2005. Role of microglia in the central nervous system's immune response. Neurol Res 27:685-691.

Takeda K, Clausen BE, Kaisho T, Tsujimura T, Terada N, Forster I, Akira S. 1999. Enhanced Th1 activity and development of chronic enterocolitis in mice devoid of Stat3 in macrophages and neutrophils. Immunity 10:39-49.

Tan-Pertel HT, Walker L, Browning D, Miyamoto A, Weinmaster G, Gasson JC. 2000. Notch signaling enhances survival and alters differentiation of 32D myeloblasts. J Immunol 165:4428-4436.

Varnum-Finney B, Xu L, Brashem-Stein C, Nourigat C, Flowers D, Bakkour S, Pear WS, Bernstein ID. 2000. Pluripotent, cytokine-dependent, hematopoietic stem cells are immortalized by constitutive Notch1 signaling. Nat Med 6:1278-1281.

Walker L, Lynch M, Silverman S, Fraser J, Boulter J, Weinmaster G, Gasson JC. 1999. The Notch/Jagged pathway inhibits proliferation of human hematopoietic progenitors in vitro. Stem Cells 17:162-171.

Wang J, Shelly L, Miele L, Boykins R, Norcross MA, Guan E. 2001. Human Notch-1 inhibits NF-kappa B activity in the nucleus through a direct interaction involving a novel domain. J Immunol 167:289295.

Wang S, Sdrulla AD, diSibio G, Bush G, Nofziger D, Hicks C, Weinmaster G, Barres BA. 1998. Notch receptor activation inhibits oligodendrocyte differentiation. Neuron 21:63-75.

Washburn T, Schweighoffer E, Gridley T, Chang D, Fowlkes BJ, Cado D, Robey E. 1997. Notch activity influences the alphabeta versus gammadelta T cell lineage decision. Cell 88:833-843.

Weinmaster G. 1997. The ins and outs of notch signaling. Mol Cell Neurosci 9:91-102.

Welte T, Zhang SS, Wang T, Zhang Z, Hesslein DG, Yin Z, Kano A, Iwamoto Y, Li E, Craft JE, Bothwell AL, Fikrig E, Koni PA, Flavell RA, Fu XY. 2003. STAT3 deletion during hematopoiesis causes Crohn's disease-like pathogenesis and lethality: A critical role of STAT3 in innate immunity. Proc Natl Acad Sci USA 100:1879-1884.

Wolfer A, Bakker T, Wilson A, Nicolas M, Ioannidis V, Littman DR, Lee PP, Wilson CB, Held W, MacDonald HR, Radtke F. 2001. Inactivation of Notch 1 in immature thymocytes does not perturb CD4 or CD8T cell development. Nat Immunol 2:235-241.

Zlobin A, Jang M, Miele L. 2000. Toward the rational design of cell fate modifiers: Notch signaling as a target for novel biopharmaceuticals. Curr Pharm Biotechnol 1:83-106. 